\title{
Meningkatkan Hasil Belajar Bahasa Indonesia pada Materi Menulis Teks Cerita Fantasi Melalui Penerapan Model Pembelajaran Problem Based Learning
}

\author{
I Ketut Narsa ${ }^{1 *}$ \\ ${ }^{1}$ SMP Negeri 1 Kuta Selatan, Badung, Indonesia
}

\section{A R T I C L E I N F O}

Article history:

Received 19 February 2021

Received in revised form 30 March 2021

Accepted 10 April 2021

Available online 11 May 2021

Kata Kunci:

Hasil Belajar, Cerita

Fantasi, PBL

Keywords:

Learning Outcomes,

Fantasy Story, PBL

\begin{abstract}
A B S T R A K
Rendahnya hasil belajar Bahasa Indonesia siswa disebabkan karena penerapan model pembelajaran yang kurang mampu membuat siswa lebih aktif mengikuti kegiatan pembelajaran, sehingga diperlukan model pembelajaran yang lebih kreatif dan inovatif. Adapun tujuan penelitian ini adalah menganalisis penerapan model pembelajaran problem-based learning terhadap hasil belajar Bahasa Indonesia pada materi menulis teks cerita fantasi siswa. Penelitian ini termasuk kedalam jenis penelitian tindakan kelas dengan dua siklus. Subjek penelitian ini adalah siswa kelas VIII sebanyak 32 orang siswa. Teknik pengumpulan data pada penelitian ini dengan memberikan tes hasil belajar kepada siswa. Teknik analisis data yang digunakan pada penelitian ini adalah teknik analisis statistik deskriptif kuantitatif. Hasil penelitian yang diperoleh dalam penelitian ini pada siklus I nilai rata-rata menunjukkan 77 , sedangkan pada siklus II nilai rata-rata hasil belajar siswa menunjukkan 82 . Simpulan penelitian adalah model pembelajaran problem-based learning pada mata pelajaran Bahasa Indonesia secara efektif dapat
\end{abstract} meningkatkan hasil belajar siswa. Implikasi penelitian ini adalah mengajarkan siswa bekerjasama secara kelompok, menggunakan informasi untuk mencoba memecahkan masalah dan siswa dilatih untuk mensintesis pengetahuan serta keterampilan sebelum mereka menerapkannya pada masalah.

\begin{abstract}
A B S T R A K
The low learning outcomes of students in Indonesian is due to the inadequate application of learning models to make students more active in participating in learning activities, so that a more creative and innovative learning model is needed. The purpose of this study was to analyze the application of problem-based learning models to Indonesian learning outcomes in writing fantasy text of students. This research belongs to the type of classroom action research with two cycles. The subjects of this study were 32 students of class VIII. The data collection technique in this study was to provide learning outcomes tests to students. The data analysis technique used in this research is descriptive quantitative statistical analysis techniques. The research results obtained in this study in cycle I the average value showed 77, while in cycle II the average value of student learning outcomes showed 82. The conclusion of the study is that the problem-based learning model in Indonesian subjects can effectively improve learning outcomes. students. The implication of this research is to teach students to work in groups, use information to try to solve problems and students are trained to synthesize knowledge and skills before they apply it to problems.
\end{abstract}

\section{Pendahuluan}

Pembelajaran bahasa indonesia pada aspek menulis adalah salah satu kemampuan yang ingin dicapai dalam belajar Bahasa Indonesia bagi siswa sekolah menengah pertama, dan belajar menulis telah dipelajari oleh siswa dari mulai tingkat sekolah dasar. Menulis merupakan sebuah proses kreatif 
menuangkan gagasan dalam bentuk tulis dengan memiliki tujuan, misalnya memberitahu, meyakinkan, dan menghibur bagi yang membacanya, selain itu menulis merupakan keterampilan berbahasa yang digunakan untuk berkomunikasi secara tidak langsung atau tidak bertatap muka (Astuti, 2016; Nahdi \& Yunitasari, 2020; Sutardi, 2010).

Dalam pengajaran bahasa Indonesia kemampuan menulis perlu mendapat perhatian dan penekanan yang intensif dari guru bahasa Indonesia, karena menulis merupakan salah satu keterampilan berbahasa dalam pengajaran bahasa Indonesia di SMP yang perlu diajarkan kepada siswa (Puspidalia, 2012; Suria et al., 2019; Wahyuni, 2014). Menulis merupakan salah satu keterampilan berbahasa yang dibutuhkan untuk meningkatkan kualitas pembelajaran. Adanya penguasaan keterampilan menulis, diharapkan siswa dapat mengungkapkan gagasan, pikiran, dan perasaan yang dimilikinya setelah menjalani proses pembelajaran dalam berbagai jenis tulisan, baik fiksi maupun nonfiksi (Romelah, 2016; Sudarmi \& Burhanuddin, 2017; Ulfah \& Soenarto, 2017).

Dengan menulis, siswa mampu mengonstruk berbagai ilmu atau pengetahuan yang dimilikinya dalam sebuah tulisan, baik dalam bentuk esai, artikel, laporan ilmiah, berita, cerpen, puisi dan sebagainya. Tujuan yang diharapkan dalam pembelajaran menulis adalah agar siswa mampu memahami dan dapat mengungkapkan beberapa hal yang mereka tangkap, seperti gagasan, pendapat, pesan dan perasaan dalam bentuk tertulis (Riana \& Setiadi, 2017; Sarjono Owon, 2017; Suhartini, 2015). Salah satu kompetensi dasar menulis yang terdapat di dalam kurikulum bahasa Indonesia Sekolah Menengah pertama (SMP) adalah menulis teks cerita fantasi sesuai dengan struktur dan kaidah kebahasaan. Penuangan gagasan, ide dalam tulisan teks cerita fantasi ini memerlukan latihan yang teratur karena tanpa latihan penulisan teks fantasi tidak dapat dilakukan, karena tidak semua siswa mempunyai kemampuan dalam menuliskannya sesuai prosedur dan struktur pada teks cerita fantasi tersebut (Anggraeni et al., 2019; Budi Febriyanto, 2019; Kurniasari, 2017).

Berdasarkan pengamatan yang dilakukan peneliti pada tahap awal dari penelitian tindakan kelas ini bahwa kemampuan siswa dalam menulis teks cerita fantasi belum mencapai nilai hasil belajar yang sesuai dengan standar nilai yang diharapkan. Hasil tes awal (prasiklus) bahwa nilai yang dicapai siswa dalam menulis teks cerita fantasi adalah 63,09, dan ketuntasan belajar mencapai $41 \%$. Ini berarti hanya 7 orang siswa dari 32 orang siswa yang di evaluasi pada prasiklus yang mampu menuntaskan pembelajaran bahasa Indonesia dengan materi menulis teks cerita fantasi. Melihat kondisi siswa yang demikian itu membuat peneliti terdorong untuk melakukan Penelitian Tindakan Kelas ini, dengan berupaya untuk melakukan perbaikan-perbaikan pada siswa yang mengalami kesulitan belajar bahasa indonesia dengan materi menulis teks cerita fantasi. Solusi yang dapat dilakukan adalah dengan menerapkan model pembelajaran problem based learning.

Model pembelajaran berbasis masalah problem based learning (PBL) merupakan suatu model pembelajaran yang didasarkan pada banyaknya permasalahan yang membutuhkan penyelidikan autentik yakni penyelidikan yang membutuhkan penyelesaian yang nyata (Fitri et al., 2020; Herzon et al., 2018; Ramlawati et al., 2017). Dalam model pembelajaran ini guru memandu siswa menguraikan rencana pemecahan masalah menjadi tahap-tahap kegiatan seperti guru memberi contoh mengenai penggunaan keterampilan dan strategi yang dibutuhkan supaya tugas-tugas tersebut dapat diselesaikan guru menciptakan susasana kelas yang fleksibel dan berorientasi pada upaya penyelidikan oleh siswa.

Menurut (Putriani et al., 2017; Rosnawati et al., 2015; Sari \& Sugiyarto, 2015) bahwa pembelajaran berbasis masalah adalah suatu pendekatan pendidikan dimana masalahnya adalah titik awal dari proses pembelajaran. Biasanya, masalah didasarkan pada masalah kehidupan nyata yang telah dipilih dan diedit untuk memenuhi tujuan pendidikan dan kriteria (Arwanda et al., 2020; Fitrah, 2017; Ladimiyanto, 2014). Beberapa proses yang pembelajaran yang terlibat untuk memperoleh pengetahuan dan keterampilan, bersama-sama dengan kemampuan setiap individu untuk kemudian diterapkan pada aplikasi kehidupan yang diaplikasikan melalui model pembelajaran problem based learning.

Model pembelajaran problem based learning mengacu pada pendekatan pembelajaran yang berfokus pada proses pemecahan masalah dengan memperoleh pengetahuan yang diperlukan. Model ini memiliki kelebihan membuat siswa belajar dengan inspirasi, mengajarkan pemikiran secara kelompok, dan menggunakan informasi terkait untuk mencoba memecahkan masalah baik yang nyata maupun hipotetis, selain itu siswa dilatih untuk mensintesis pengetahuan dan keterampilan sebelum mereka menerapkannya pada masalah, sehingga materi yang diberikan mudah diingat oleh siswa (Abdurrozak \& Jayadinata, 2016; Christiana et al., 2014; Defiyanti \& Sumarni, 2019).

Penelitian ini didukung oleh penelitian-penelitian sebelumnya yang relevan dengan pnelitian ini seperti: (1) penelitian oleh (Febriana et al., 2020), yang memperoleh hasil penelitian yaitu modul pembelajaran berbasis problem based learning berpengaruh terhadap kreativitas pemecahan masalah siswa; (2) penelitian oleh (Istiandaru et al., 2015), yang memperoleh hasil penelitian yaitu model pembelajaran problem based learning (PBL) dengan pendekatan realistik-saintifik dan asesmen PISA 
berpengaruh positif tehadap kemampuan literasi matematika siswa; (3) penelitian oleh (Ariswati, 2018), yang memperoleh hasil penelitian yaitu model pembelajaran problem based learning berpengaruh terhadap hasil belajar matematika siswa.

Tujuan penelitian ini adalah menganalisis penerapan model pembelajaran problem based learning terhadap hasil belajar Bahasa Indonesia pada materi menulis teks cerita fantasi siswa kelas VIII semester ganjil SMP Negeri 1 Kuta Selatan tahun pelajaran 2018/2019.

\section{Metode}

Penelitian ini termasuk kedalam jenis penelitian tindakan kelas dengan dua siklus. Penelitian ini dilakukan di Kelas VIII SMP Negeri 1 Kuta Selatan, yang beralamatkan di Jl. Wanagiri, Jimbaran, Kuta Selatan, Jimbaran, Kabupaten Badung. Subyek Penelitian ini adalah siswa kelas VIII semester Ganjil SMP Negeri 1 Kuta Selatan yang berjumlah 32 orang. Waktu penelitian mulai dari perencanaan sampai dengan penulisan laporan hasil penelitian tersebut mulai dari bulan Juli s.d Desember tahun 2018 dan penulisan laporan dilakukan sampai dengan bulan Desember, pada semester ganjil tahun pelajaran 2018/2019. Metode pengumpulan data yang digunakan pada penelitian ini adalah dengan pemberian tes. Metode ini digunakan pada saat penelitian dengan cara memberikan tes hasil belajar kepada siswa kelas VIII SMP Negeri 1 Kuta Selatan yang berjumlah 32 orang. Setelah seluruh data terkumpul, dilanjutkan dengan metode analisis data yakni metode analisis data statistik deskriptif kuantitatif. Indikator keberhasilan penelitian ini adalah peningkatan hasil belajar siswa pada mata pelajaran Bahasa Indonesia tentang materi menulis teks cerita fantasi dengan optimal dan ketuntasan belajar siswa dapat dicapai dengan baik bagi siswa kelas VIII SMP Negeri 1 Kuta Selatan.

\section{Hasil dan Pembahasan}

Berdasarkan penelitian yang telah dilakukan dengan menerapkan model pembelajaran problem based learning didapatkan hasil berupa kegiatan pembelajaran di siklus I dilaksanakan sesuai program yang telah dirancang dan penerapan model pembelajaran problem based kearning telah menunjukkan bukti bahwa siswa mampu meningkatkan dan pemahaman siswa terhadap materi pelajaran bahasa Indonesia tentang menulis teks cerita fantasi yang dilaksanakan dalam pembelajaran pada Penelitian Tindakan Kelas ini lebih baik dari prasiklus. Keberhasilan yang dicapai pada siklus I dapat memacu semangat belajar lebih baik dari prasiklus.

Dari paparan hasil siklus I rata-rata nilai yang dicapai bsiswa adalah sebagai berikut: (1) ratarata nilai siklus I = 77; (2) ketuntasan belajar mencapai = 75\%; (3) siswa yang belum tuntas $=25 \%$; (4) terjadi peningkatan ketutasan belajar dari prasiklus sebanyak 34\%; (5) siswa dapat memahami tentang mekanisme penulisan teks cerita fantasi sesuai nprosedur dan berlatih dengan cermat; (6) peningkatan hasil pembelajaran yang dicapai pada siklus I karena Peneliti menerapkan model pembelajaran Problem Based Learning dimana siswa diberi bimbingan secara kontinju sampai mencapai kemahiran dalam menuangkan ide, gagasan serta konsep yang dimilikinya dalam menulis teks cerita fantasi; (7) siswa mulai membuka wawasan dan membaca literatur terkait dengan penulisan teks cerita fantasi dalam upaya meningkatkan ketrampilannya pada aspek menulis; (8) dengan diberikan bimbingan yang intensif siswa merasa terbina dan terfasilitasi untuk maju.

Hasil pembelajaran yang dicapai pada siklus II berdasarkan penerapan model pembelajaran Problem Based Learning secara konsisten dapat meningkatkan semangat belajar siswa sehingga hasil yang dicapai dapat dideskripsikan sebagai berikut: (1) nilai rata-rata yang dicapai di siklus II = 82; (2) ketuntasan belajar mencapai $=100 \%$; (3) sebanyak 32 siswa telah mampu menuntaskan pembelajaran di siklus II secara optimal; (4) siswa dapat menulis teks cerita fantasi dengan baik sesuai prosedur; (5) peningkatan hasil yang dicapai siswa pada siklus II karena dilakukan refleksi secara maksimal melalui penerapan model pembelajaran Problem Based Learning; (6) siswa merasa terbina kemampuannya untuk melakukan editing tentang hasil penulisan teks cerita fantasi yang telah dihasilkannya melalui pembelajaran; (7) hasil yang dicapai pada siklus II merupakan hasil akhir dari penelitian tindakan kelas ini; (8) seluruh siswa yang menjadi subjek dalam Penelitian Tindakan Kelas ini telah menuntaskan pembelajaran bahasa Indonesia dengan materi menulis teks cerita fantasi bsecara optimal.

Dari data nilai hasil evaluasi siswa kelas VIII SMP Negeri 1 Kuta Selatan, pada siklus II yang telah menunjukkan peningkatan, dan adanya pengaruh yang positif terhadap penerapan model pembelajaran Problem Based Learning, dalam belajar mata pelajaran bahasa Indonesia dengan materi menulis teks cerita fantasi. Dengan demikian penerapan model pembelajaran Problem Based Learning telah terbukti keberhasilannya dengan baik. Rekspitulasi hasil penelitian yang telah dicapai dalam penelitian tindakan kelas ini dapat disajikan pada Tabel 1. 
Tabel 1. Rekapitulasi Hasil Penelitian

\begin{tabular}{llcccc}
\hline \multirow{2}{*}{ No. } & \multicolumn{1}{c}{ Kreteria } & \multicolumn{3}{c}{ Jenis Tindakan } & \multirow{2}{*}{ Ket. } \\
\cline { 3 - 5 } & & Pre test/Prasiklus & S.I & S.II & \\
\hline 1. & Jumlah Nilai & 2076 & 2448 & 2626 & Meningkat \\
2. & Rata-rata Nilai & 65 & 77 & 82 & Meningkat \\
3. & Ketuntasan Belajar & $41 \%$ & $75 \%$ & $100 \%$ & Meningkat \\
4 & Siswa Yang Belum Tuntas & $59 \%$ & $25 \%$ & 0 & Meningkat \\
\hline
\end{tabular}

Berdasarkan Tabel 1, hasil penelitian yang diperoleh dalam penelitian ini pada siklus I nilai ratarata menunjukkan 77 , sedangkan pada siklus II nilai rata-rata hasil belajar siswa menunjukkan 82 , hal ini membuktikan bahwa model pembelajaran problem based learning pada mata pelajaran Bahasa Indonesia secara efektif dapat meningkatkan hasil belajar siswa.

Model pembelajaran berbasis masalah problem based learning ( $P B L$ ) merupakan suatu model pembelajaran yang didasarkan pada banyaknya permasalahan yang membutuhkan penyelidikan autentik yakni penyelidikan yang membutuhkan penyelesaian yang nyata (Fitri et al., 2020; Herzon et al., 2018; Ramlawati et al., 2017). Dalam model pembelajaran ini guru memandu siswa menguraikan rencana pemecahan masalah menjadi tahap-tahap kegiatan seperti guru memberi contoh mengenai penggunaan keterampilan dan strategi yang dibutuhkan supaya tugas-tugas tersebut dapat diselesaikan guru menciptakan susasana kelas yang fleksibel dan berorientasi pada upaya penyelidikan oleh siswa.

Menurut (Putriani et al., 2017; Rosnawati et al., 2015; Sari \& Sugiyarto, 2015) bahwa pembelajaran berbasis masalah adalah suatu pendekatan pendidikan dimana masalahnya adalah titik awal dari proses pembelajaran. Biasanya, masalah didasarkan pada masalah kehidupan nyata yang telah dipilih dan diedit untuk memenuhi tujuan pendidikan dan kriteria (Arwanda et al., 2020; Fitrah, 2017; Ladimiyanto, 2014).

Model pembelajaran problem based learning mengacu pada pendekatan pembelajaran yang berfokus pada proses pemecahan masalah dengan memperoleh pengetahuan yang diperlukan. Model ini memiliki kelebihan membuat siswa belajar dengan inspirasi, mengajarkan pemikiran secara kelompok, dan menggunakan informasi terkait untuk mencoba memecahkan masalah baik yang nyata maupun hipotetis, selain itu siswa dilatih untuk mensintesis pengetahuan dan keterampilan sebelum mereka menerapkannya pada masalah, sehingga materi yang diberikan mudah diingat oleh siswa (Abdurrozak \& Jayadinata, 2016; Christiana et al., 2014; Defiyanti \& Sumarni, 2019).

Penelitian ini didukung oleh penelitian-penelitian sebelumnya yang relevan dengan pnelitian ini seperti: (1) penelitian oleh (Febriana et al., 2020), yang memperoleh hasil penelitian yaitu modul pembelajaran berbasis problem based learning berpengaruh terhadap kreativitas pemecahan masalah siswa; (2) penelitian oleh (Istiandaru et al., 2015), yang memperoleh hasil penelitian yaitu model pembelajaran problem based learning $(P B L)$ dengan pendekatan realistik-saintifik dan asesmen PISA berpengaruh positif tehadap kemampuan literasi matematika siswa; (3) penelitian oleh (Ariswati, 2018), yang memperoleh hasil penelitian yaitu model pembelajaran problem based learning berpengaruh terhadap hasil belajar matematika siswa.

Implikasi penelitian ini adalah mengajarkan siswa bekerjasama secara kelompok, menggunakan informasi untuk mencoba memecahkan masalah dan siswa dilatih untuk mensintesis pengetahuan serta keterampilan sebelum mereka menerapkannya pada masalah.

\section{Simpulan}

Pada penelitian ini disimpulkan bahwa model pembelajaran problem based learning pada mata pelajaran Bahasa Indonesia secara efektif dapat meningkatkan hasil belajar siswa pada materi menulis teks cerita fantasi kelas VIII.12 semester ganjil SMP Negeri 1 Kuta Selatan. Implikasi penelitian ini adalah mengajarkan siswa bekerjasama secara kelompok, menggunakan informasi untuk mencoba memecahkan masalah dan siswa dilatih untuk mensintesis pengetahuan serta keterampilan sebelum mereka menerapkannya pada masalah.

\section{Daftar Rujukan}

Abdurrozak, R., \& Jayadinata, A. K. (2016). Pengaruh Model Problem Based Learning Terhadap Kemampuan Berpikir Kreatif Siswa. Jurnal Pena Ilmiah, 1(1), 871-880. https://doi.org/10.23819/pi.v1i1.3580 
Anggraeni, R., Sulton, S., \& Sulthoni, S. (2019). Pengaruh Multimedia Tutorial Terhadap Hasil Belajar Bahasa Indonesia. Jurnal Kajian Teknologi Pendidikan, 2(2), 96-101. https://doi.org/10.17977/um038v2i22019p096

Ariswati, N. P. E. A. (2018). Pengaruh Model Pembelajaran Problem Based Learning Terhadap Hasil Belajar Matematika Siswa Kelas V Sd Negeri Nanggulan. Mimbar PGSD, 6(4). https://doi.org/10.1590/s1809-98232013000400007

Arwanda, P., Irianto, S., \& Andriani, A. (2020). Pengembangan Media Pembelajaran Articulate Storyline Kurikulum 2013 Berbasis Kompetensi Peserta Didik Abad 21 Tema 7 Kelas IV Sekolah Dasar. AlMadrasah: Jurnal Pendidikan Madrasah Ibtidaiyah. https://doi.org/10.35931/am.v4i2.331

Astuti, A. P. (2016). Pengembangan Instrumen Penilaian Kompetensi Membaca Pada Mata Pelajaran Bahasa Indonesia Kelas VII Berbasis Quipper School. JINoP (Jurnal Inovasi Pembelajaran), 2(2), 334-350. https://doi.org/10.22219/jinop.v2i2.3635

Budi Febriyanto. (2019). Metode Cerita Berantai Untuk Meningkatkan Keterampilan Berbicara Siswa Pada Pembelajaran Bahasa Indonesia. Jurnal Cakrawala Pendas, 5(2), 40-44. https://doi.org/10.31949/jcp.v5i2.1388

Christiana, P. P., Suniasih, N. W., \& Suadnyana, I. N. (2014). Pengaruh Model Problem Based Learning Berbasis Penilaian Proyek terhadap Kemampuan Berpikir Kritis IPA SD Gugus VIII Sukawati. EJournal Mimbar PGSD Universitas Pendidikan Ganesha, 2(1). https://doi.org/10.23887/jjpgsd.v2i1.2031

Defiyanti, \& Sumarni, W. (2019). Analisis Kemampuan Berpikir Kritis Peserta Didik Pada Penerapan Problem Based Learning Berbantuan Lembar Kerja Peserta Didik Bermuatan Etnosains. Phenomenon, 09(2), 206-218. https://doi.org/10.21580/phen.2019.9.2.4200

Febriana, R., Yusri, R., \& Delyana, H. (2020). Modul Geometri Ruang Berbasis Problem Based Learning Terhadap Kreativitas Pemecahan Masalah. Aksioma: Jurnal Program Studi Pendidikan Matematika, 9(1), 93. https://doi.org/10.24127/ajpm.v9i1.2591

Fitrah, M. (2017). Pembelajaran Berbasis Masalah Untuk Meningkatkan Pemahaman Konsep Matematika Pada Materi Segiempat Siswa Smp. Kalamatika: Jurnal Pendidikan Matematika, 2(1), 51. https://doi.org/10.22236/kalamatika.vol2no1.2017pp51-70

Fitri, M., Yuanita, P., \& Maimunah, M. (2020). Pengembangan Perangkat Pembelajaran Matematika Terintegrasi Keterampilan Abad 21 Melalui Penerapan Model Problem Based Learning (PBL). Jurnal Gantang, 5(1), 77-85. https://doi.org/10.31629/jg.v5i1.1609

Herzon, H. H., Budijanto, \& Utomo, D. H. (2018). Pengaruh Problem-Based Learning (PBL) terhadap Keterampilan Berpikir Kritis. Jurnal Pendidikan: Teori, Penelitian, Dan Pengembangan, 3(1), 4246. http://journal.um.ac.id/index.php/jptpp/

Istiandaru, A., Istihapsari, V., Wardono, \& Mulyono. (2015). Problem Based Learning (PBL) dengan Pendekatan Realistik-Saintifik dan Asesmen PISA untuk Meningkatkan Kemampuan Literasi Matematika. Edumatica, 5(1), 1-11. https://doi.org/10.22437/edumatica.v5i01.2670

Kurniasari, F. (2017). Implementasi Pendekatan Saintifik Pada Penugasan Aktivitas Di Buku Teks Bahasa Indonesia Kelas VII SMP Berdasarkan Kurikulum 2013. Jurnal Pendidikan Edutama, 4(1), 9-26. https://doi.org/10.30734/jpe.v4i1.44

Ladimiyanto, A. (2014). Pengaruh Implementasi Pembelajaran Berbasis Masalah dengan Model TAI dan TPS terhadap Hasil Belajar Matematika. Pythagoras: Jurnal Pendidikan Matematika, 9(2), 110 125. https://doi.org/10.21831/pg.v9i2.9073

Nahdi, K., \& Yunitasari, D. (2020). Literasi Berbahasa Indonesia Usia Prasekolah: Ancangan Metode Dia Tampan dalam Membaca Permulaan. Jurnal Obsesi : Jurnal Pendidikan Anak Usia Dini, 4(1), 434441. https://doi.org/10.31004/obsesi.v4i1.372

Puspidalia, Y. S. (2012). Problematika Pembelajaran Bahasa Indonesia Di Mi/Sd Dan Alternatif Pemecahannya. Cendekia: Jurnal Kependidikan Dan Kemasyarakatan, 10(1). https://doi.org/10.21154/cendekia.v10i1.406

Putriani, N. P. D., Mahadewi, L. P. P., \& Rati, N. wayan. (2017). Pengaruh Model Pembelajaran Value Clarification Technique (VCT) Berbasis Masalah Sosial Terhadap Hasil Belajar PKN Siswa Kelas V. 
Mimbar PGSD Undiksha, 5(2). https://doi.org/10.23887/jjpgsd.v5i2.10887

Ramlawati, Yunus, S. R., \& Insani, A. (2017). Pengaruh Model PBL (Problem Based Learning) terhadap Motivasi dan Hasil Belajar IPA Peserta Didik. Jurnal Sainsmat, 6(1), 1-14. https://ojs.unm.ac.id/sainsmat/article/view/6451

Riana, R., \& Setiadi, S. (2017). Penerapan Model Pembelajaran Kooperatif Teknik Mind Mapping Dalam Meningkatkan Keterampilan Menulis Karangan Narasi Ekspositoris Pada Mata Pelajaran Bahasa Indonesia Peserta Didik Kelas XII Smk Swadaya, Semarang. Jurnal Dinamika Sosial Budaya, 18(1), 109. https://doi.org/10.26623/jdsb.v18i1.562

Romelah. (2016). Peningkatan Kemampuan Menulis Puisi Dengan Teknik Kata Mengalir Berbantuan Media Benda Konkret Pada Siswa Kelas VIII SMPN 5 Pagentan. Lingua: Journal of Language, Literature and Teaching, 13(1), 59-72. https://doi.org/10.30957/lingua.v13i1.11

Rosnawati, Atmaja, H. ., \& Suhandini, P. (2015). Pengembangan Model Pembelajaran Berbasis Masalah Bermain Peran Untuk Peningkatkan Rasa Cinta Tanah Air Siswa Kelas V Pada Materi Proklamasi Kemerdekaan. Journal of Primary Education, 4(2), 147-151. https://doi.org/10.15294/jpe.v4i2.10977

Sari, D. S., \& Sugiyarto, K. H. (2015). Pengembangan Multimedia Berbasis Masalah Untuk Meningkatkan Motivasi Belajar Dan Kemampuan Berpikir Kritis Siswa. Jurnal Inovasi Pendidikan IPA, 1(2), 153166. https://doi.org/10.21831/jipi.v1i2.7501

Sarjono Owon, R. A. (2017). Pengembangan Bahan Ajar Menulis Berbagai Jenis Teks Bertema Kearifan Lokal Sikka Bagi Siswa SMP. JINoP (Jurnal Inovasi Pembelajaran), 3(1), 528-541. https://doi.org/10.22219/jinop.v3i1.4318

Sudarmi, S., \& Burhanuddin, B. (2017). Keefektifan Model Pembelajaran Kooperatif Tipe Scramble Dalam Keterampilan Menulis Kalimat Bahasa Jerman Siswa Kelas Xi Sma Negeri 11 Makassar. Eralingua: Jurnal Pendidikan Bahasa Asing Dan Sastra, 1(1). https: //doi.org/10.26858/eralingua.v1i1.2991

Suhartini, S. (2015). Peningkatan Keterampilan Menulis Naskah Drama Satu Babak Menggunakan Model Think-Pair-Share Berbantuan Alat Peraga Gambar Berseri. Satya Widya, 31(2), 83-89. https://doi.org/10.24246/j.sw.2015.v31.i2.p83-89

Suria, M. D. O., Suwatra, I. W., \& Murda, N. (2019). Pengaruh Model Pembelajaran Snowball Throwing Berbantuan Media Audiovisual terhadap Hasil Belajar Bahasa Indonesia. Jurnal Ilmiah Sekolah Dasar, 3(1), 89. https://doi.org/10.23887/jisd.v3i1.17662

Sutardi, A. (2010). Model Penilaian Bahasa Indonesia Dalam Pelaksanaan Kurikulum Sekolah Dasar. Jurnal Pendidikan Dan Kebudayaan, 16(2), 215-227. https://doi.org/10.24832/jpnk.v16i2.455

Ulfah, D. M., \& Soenarto, S. (2017). Pengaruh penggunaan media video dan gambar terhadap keterampilan menulis kelas V. Jurnal Prima Edukasia, 5(1), 22-34. https://doi.org/10.21831/jpe.v5i1.7693

Wahyuni, S. (2014). Pengembangan Interactive E-Book Bidang Asesmen Bahasa Untuk Mengembangkan Kompetensi Dan Kemandirian Mahasiswa Program Pendidikan Bahasa. Litera, 13(1), 128-139. https://doi.org/10.21831/ltr.v13i1.1908 